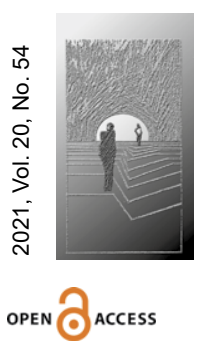

\title{
The Daily Life of Contemporary Mothers - Between Social Expectations, the Sense of Duty and the Individual Experience of Motherhood
}

\begin{abstract}
:
RESEARCH OBJECTIVE: The aim of this paper is to present the dilemmas of everyday life of contemporary mothers related to society's expectations of motherhood and their individual experiences.
\end{abstract}

THE RESEARCH PROBLEM AND METHODS: The research problem was the (re)construction of everyday life of modern mothers during a pandemic. The narrative interview technique was used in the research.

THE PROCESS OF ARGUMENTATION: This article analyzes how mothers experience motherhood during a pandemic against the background of social transformations. The issue of everyday life as an important category was presented in the considerations contained in the article below. Then, the methodological assumptions and research results focused on the issues of the multiplicity of choices in the present day and the difficulties associated with them, as well as the everyday life of mothers, were presented. The article ends with reflections on the situation of mothers in the context of contemporary challenges.

RESEARCH RESULTS: A conclusion can be drawn about the positioning of motherhood between the traditional and modern pattern of the ideal mother. First of all, mothers feel tired of the seriousness of the role they play, and from fulfilling which many people can "hold them accountable".

CONCLUSIONS, INNOVATIONS, AND RECOMMENDATIONS: The conducted research shows interesting conclusions pointing to changes related to the perception of the role of the mother in modern times. They contribute to the undertaking of more extensive research on the need for (re)construction of motherhood.

$\rightarrow$ KEYWORDS: PEDAGOGY, MOTHERHOOD, CHILD, FAMILY, DAILY LIFE, DILEMMAS 


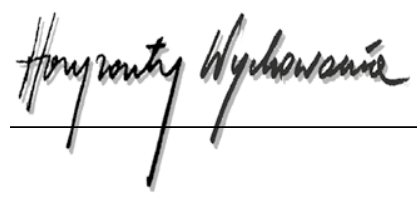

\section{STRESZCZENIE}

Życie codzienne współczesnych matek - między oczekiwaniami społecznymi, poczuciem obowiązku a indywidualnym doświadczaniem macierzyństwa

CEL NAUKOWY: Celem artykułu jest przedstawienie dylematów życia codziennego współczesnych matek związanych z oczekiwaniami społeczeństwa wobec macierzyństwa i ich indywidualnymi doświadczeniami.

PROBLEM I METODY BADAWCZE: Problemem badawczym była (re)konstrukcja życia codziennego współczesnych matek $w$ trakcie trwania pandemii. W badaniu wykorzystano technikę wywiadu narracyjnego.

PROCES WYWODU: Artykuł analizuje, jak matki doświadczają macierzyństwa podczas pandemii na tle przemian społecznych. Problematyka życia codziennego jako ważnej kategorii została przedstawiona w rozważaniach zawartych w poniższym artykule. Następnie przedstawiono założenia metodologiczne i wyniki badań skoncentrowanych na problematyce wielości wyborów w teraźniejszości i związanych z nimi trudnościach oraz życia codziennego matek. Artykuł kończy się refleksją na temat sytuacji matek w kontekście współczesnych wyzwań.

WYNIKI ANALIZY NAUKOWEJ: Na podstawie przeprowadzonych badań można sformułować wniosek o umiejscowieniu macierzyństwa pomiędzy tradycyjnym a nowoczesnym wzorcem idealnej matki. Przede wszystkim matki czują się zmęczone powagą roli, jaką odgrywają, i wypełnianiem jej, z której wielu ludzi może „pociągnąć ich do odpowiedzialności”.

WNIOSKI, INNOWACJE, REKOMENDACJE: Przeprowadzone badania prezentują interesujące wnioski wskazujące na zmiany związane z postrzeganiem roli matki w czasach współczesnych. Przyczyniają się do podjęcia szerszych badań nad potrzebą (re)konstrukcji macierzyństwa.

$\rightarrow$ SŁOWA KLUCZOWE: PEDAGOGIKA, MACIERZYŃSTWO, DZIECKO, RODZINA, ŻYCIE CODZIENNE, DYLEMATY

\section{Introduction}

The belief that motherhood constitutes the calling of every woman is widespread in traditional societies of various cultural backgrounds. It is seen as a woman's basic biological and social role. This belief has taken the form of "a dictate of motherhood." Women who failed to fulfil this duty felt undervalued regardless of activities and achievements in other spheres of social life (Gawlina, 2003, p. 34).

The contemporary times along with the ongoing social and cultural changes have given people the opportunity to choose between various life priorities. More often than not, motherhood is seen as only one of the available options. When it is chosen, motherhood can be shaped within the area between biological and social determinants. It can 
be an independent, voluntary and personal decision. A woman can, but does not have to, become a mother. She can successfully pursue self-fulfilment in other spheres of life (Mitręga, 2014, p. 56; Bieńko, 2015, p. 91). It can be treated as a project ("a parenting project"). Women's decision to become (not to become) a mother is under the influence of elements describing the reality of motherhood, the values related to being a parent as well as subjectively felt threats. Motherhood is a very personal sphere (Mitregga, 2014, pp. 56-57), though it loses this privilege of privacy on many occasions. Social expectations from mothers are increasing and they more intensely felt by mothers.

When a child is born, the mother's life is changed fundamentally, i.e. it is a life change event. Such an event pertains to important matters and precious values with the simultaneous experience of the sense of inefficiency of the previous ways of functioning, the sense of tension, inadequacy of competences and requirements; all of this motivates individuals to change their life and behaviour (Włodarczyk, 2017, pp. 53-66).

Daily life is a notion with multiple meanings. It is pointed out by e.g. Wysocka who refers to Waldenfels and his three possible interpretations of this notion. Dailiness can be recognised as a term which defines what is ordinary and perceived in the categories of an organisational order. The second interpretation of daily life point to what is concrete and "empirically perceptible." Dailiness understood as elements of reality ("enclosed and tied") is the third way of conceiving this notion. The key essential features of daily life include the following categories: ordinariness, concreteness as well as spatial and temporal immediacy. Dailiness has two dimensions: temporal (biographical, historical) and spatial (place, living space). It is interpreted as an inevitable category which is inextricably linked with the attachment of values which determine the way people function in their daily life (Wysocka, 2010, pp. 398-399).

Dailiness is also a popular category which has its significance and defines the form and the condition of human life (Wysocka, 2010, p. 401). Daily life is characterised by order, repetition and routine in various situations, activities performed by an individual. An ambivalent feature of dailiness is the routine which may lead to reluctant repetition of ordinary and common activities (Skoczylas-Namielska, 2020, pp. 169-173). From this perspective daily life is experienced negatively due to its monotony (depreciation of dailiness). On the other hand, this routine ensures the sense of safety and stability (Wysocka, 2010, p. 402).

\section{Methodological assumptions}

The research has made the dilemmas of modern women related to motherhood in the context of individual experiences and social expectations. The purpose of the interviews was to obtain information about the (non) fulfilment of the social expectations of motherhood.

From the point of view of the research subject, I was interested in women's dilemmas related to motherhood and social expectations. Narrative research makes it possible to achieve this objective. I used the biographical method (Smolinska-Theiss \& Theiss, 2010, p. 85; Lalak, 2010, p. 259). It allows us to reconstruct and interpret the 


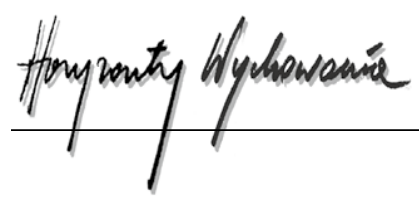

experiences associated with an individual biography, to gather information about the individual perception by mothers of the world, themselves and others, and the experiences associated with it (Jakob, 2001, p. 111; Ostrouch-Kamińska, 2011, p. 136; NowakDziemianowicz, 2002, pp. 62-63). I used a narrative interview, which is one of the forms on biography (Rubacha, 2008, pp. 290-291). Interviews were conducted using instant messaging. Such a form of intelligence is beneficial when is no possibility of direct observation (Konarzewski, 2000, pp. 78-81; Creswell, 2013, p. 195).

The research problem was formulated as follows: What are the dilemmas (if there are any) related to motherhood experiencing by contemporary mothers?

1. Are there, and if so, what are society's expectations of motherhood?

2. What are the experiences related to reconciling the roles of mothers and employees of the surveyed mothers?

3. What difficulties do they experience in relation to social expectations and individual perceptions of motherhood?

The study participants were 10 women-mothers from the Kuyavian-Pomeranian Voivodeship. Their shared qualities included higher education (of various profiles) and the age between 25 and 35 years. $5 \mathrm{~s}$. 5 women were married, 4 had a partner and one was a single mother (divorced). The choice criterion was being a mother of a child up to 3 years old. Therefore, it was non-probability sampling (purposive). The study was conducted at the turn of July and August 2020.

The starting point has been an interpretive paradigm, which is based on the discovery of a central structure of meaning in a person's biography. Proponents of this paradigm share the belief that reality is shared by the various constructs used by researcher and the researcher, and that knowledge is of a social nature and social interpretation of realities under certain social conditions. The interpretative paradigm explains how human copes the world, what meanings he gives reality, how he defines himself, what visions of life he constructs (Smolinska-Theiss \& Theiss, 2010, pp. 81-82; Rubacha, 2008, pp. 308310; Creswell, 2013, p. 31).

The theoretical basis was provided by Havighurst's developmental task theory which asserts that a human individual moves from one stage to another by solving problems typical of the given period. A developmental task is a task which emerges at the specific time in a person's life. The developmental tasks in early adulthood include the choice of a spouse/partner, starting a family, learning family roles and childcare, upbringing of children (Trempała, 2000, p. 49; Palus, 2010, p. 9).

Referring to Rubacha in the narrative material, the researcher avoids imposing on the data any structures by which data will be analyzed. This is based on the assumption that "the narrative doesn't reproduce events in their actual course, but is a source of data on how a person perceives and interprets them at present" (Rubacha, 2008, p. 300). The analysis of the collected material was carried out in terms of ${ }^{1}$ : multiplicity

${ }^{1}$ The text presented below contains a discussion on the preliminary research results. It can be treated as prolegomena to the further proper research. 
of choices and related difficulties social expectations, perceptions of motherhood, tiredness of everyday life, support provided.

\section{Parenting filled with tensions - social expectations and multiplicity of choices}

Mothers strongly feel the social pressure which expects them to be ideal. They speak of the tension they feel in situations of information chaos and uncertainty in making decisions. They perceive contradictions in the multiple recommended models of behaviour for contemporary and future mothers. These contradictions lead to uncertainty which follows from the lack of clear-cut models of conduct. On the one hand, the possibility of choice given to people is a value, but on the other hand it can also be a serious burden, as pointed out by one of the mothers:

You face such dilemmas as going back to work after the maternal leave or staying home
with the child. Nowadays, we can choose the duration of the leave. But do you think it makes
things easier? No, this possibility of choice is sometimes even more difficult. You don't know
what the society wants from you exactly... whether you are supposed to stay home with
the child as long as possible or you should be a super mum, quickly return to work and
reconcile everything perfectly well. It's best to have the kind of work where you can bring
the child with you, since if celebrities can do it, so that's what is expected from us as well.

One may also put forward a thesis that on the one hand mothers are under pressure to stay home with the child instead of going to work, while on the other hand the childcare and house chores on a full-time basis do not enjoy social appreciation (Sikorska, 2012, p. 111).

A women can make an individual choice, which makes her feel enabled, but regardless of her decision she can experience a sense of guilt and uncertainty whether the choice she made is actually optimal.

Special difficulties occur when the family life needs to be somehow reconciled with work. The traditional society ensured the mutual independence and separation of family roles and occupational roles. Nowadays, the high complexity and diversity of professional duties blur the boundaries between private time and working time. On the one hand, women fully enjoy the right to work and promotions (i.e. a professional career), but it is also emphasised that a woman needs a child to become self-fulfilled. The worklife balance is becoming the Holy Grail of contemporary people. If a women works, she is deemed an egoist who harms her family. At the same time, mothers who do not work are seen as those who "do nothing" (Bieńko, 2015, p. 97).

I seem to be moving lamely between home and work. I try to let go where I can. Either at work or at home. I have many things left unfinished. I do what I have to in the first place. I leave other stuff for "later." 


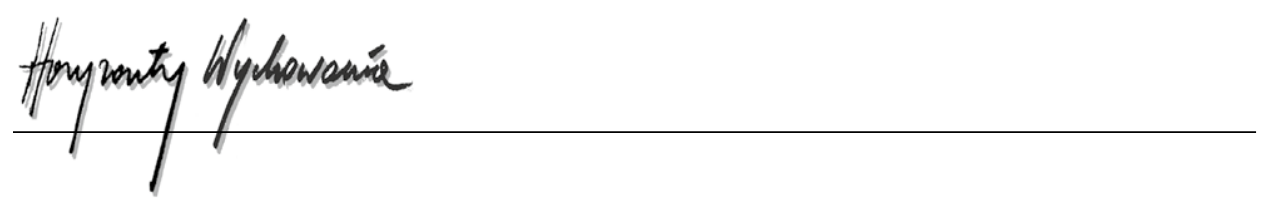

I and my husband decided that I would look after our daughter until the kindergarten time.

I often hear comments made by my female friends and closest relatives who say that I have permanent vacation just sitting at home and resting.

Some of the surveyed mothers reconcile their family life with work without facing a conflict of roles. One of them says:

I know that my child is looked after well. I don't need to worry about it. It makes it easier for me at work. I don't need to check my phone every minute or call to makes sure everything is OK, because I know it is OK.

More and more is expected from mothers and motherhood as such is compared to one of the Olympic disciplines where the characteristic feature consists in being a champion in the world governed by rivalry. A child is seen as the "certificate" of parenting skills, especially of the mother's parenting skills (Bieńko, 2015, p. 95). The social expectations perceived by mothers repeatedly lead to mental and physical exhaustion.

\begin{abstract}
We are expected to be robots, made of stone, who never get tired and never give up. We are supposed keep abreast of everything and meet all the expectations. Preferably with a smile on the face, since the ideal mother cannot be weak. She must never show how tired she is.

I have no will to do anything. I feel physically and mentally exhausted. This sense of being controlled by everybody at each step is unbearable. Whatever I do, it's going to be wrong. There is no good choice here. It makes me all drained and worn out.
\end{abstract}

The discourse in the mass media portrays motherhood as a source of infinite joy. Mothers receive the following message from the society: motherhood is a mission. In order to carry out this mission, they have to give up their passions and professional ambitions (at least for a certain period of time) and focus all their energy on the child. A women should experience joy, ease and self-fulfilment in connection with the mission of motherhood. The mother's image promoted in the media and cultivated by the society shows a great women who loves her offspring unconditionally and selflessly. In fact, this often leads to situations in which mothers are left all alone with their problems and hardships. They feel misunderstood by the society at large and by people close to them; they feel judged and perceived as bad mothers who fail to meet expectations and are worse than others (Sikorska, 2012, pp. 21-30). This is expressed by one of the mothers:

I have the impression that it is hard to be a mother today. All around, in the media, in newspapers and on the Internet, I see the image of the ideal mum. We are put under the obligation to be perfect. We are supposed be rested and brimming with energy. We are supposed to bubble with happiness. The house must be thoroughly clean. The child must be properly taken care of. I try to do all of this, to be like this. I hide my fatigue from my closest people. I hide my frustration as well. 
One of the essential features of contemporary motherhood is the nearly incessant being with the child. The surveyed mothers realize they have to keep abreast of everything. They need to be experts and they know there is no place for any negligence in the matters related to the child's physical and mental development.

I try to keep up to date when it comes to upbringing. I read a lot. I ask for advice. I strive not to overlook anything. I do not want to feel pangs of conscience, because I failed to notice something at the right moment...

\section{The daily life of mothers - "I fail to be perfect..."}

Motherhood can be treated as a turning point in a woman's life. It is a radical breakthrough that leads to "another world". It is a world of responsibility for another human being, endless duties and renunciation of one's own needs. Each decision should now consider the child and its needs (Budrowska, 2000, pp. 239-248).

The child changes just about everything. The whole day and all activities are dictated by the child. All of our duties change. The world turns upside down. It's all different.

Nowadays, the above way of understanding and experiencing motherhood is gradually abandoned. More often motherhood is described without retouches. Uncertainty, imperfection and fatigue are allowed to enter the picture. The uncertainty felt by mothers results from the multiple models of motherhood from which a contemporary woman can choose. The experience of uncertainty can be perceived as the result of the changed relationship between the parent and the child to the approach of subjectification and partnership. The consequences of this change include difficulties in interpreting the role of the parent and of the child as well as in providing a precise description of the relationship (Sikorska, 2012, pp. 18-19).

\footnotetext{
I have always heard people talk about the maternal instinct, that it's normal and necessary, that it has to be like that. When I gave birth to my child, I was simply unable to love it. I didn't feel it, though I knew it was my duty. I was afraid to tell anyone about it, I was afraid of being misunderstood. That's why I did what I was supposed to. I tried to fulfil my maternal duties. I hugged and fed the child. I got up at night. It was hard. Thanks to my husband whom I finally told about my problem I discovered the love for my child in me. Today I can't imagine my life without my child.
}

Motherhood is no longer perceived strictly in terms of "mission" and the only choice for a woman. More and more often, it is placed outside the sphere of "duty" and defined as an autonomous decision wherein the woman-mother uses rational analyses to understand and assess her life situation.

I try to approach it all rationally. I love my child. I love my family, but I also love my job. I like being among people. I like it when I feel important. I like it when I pursue self-fulfilment 


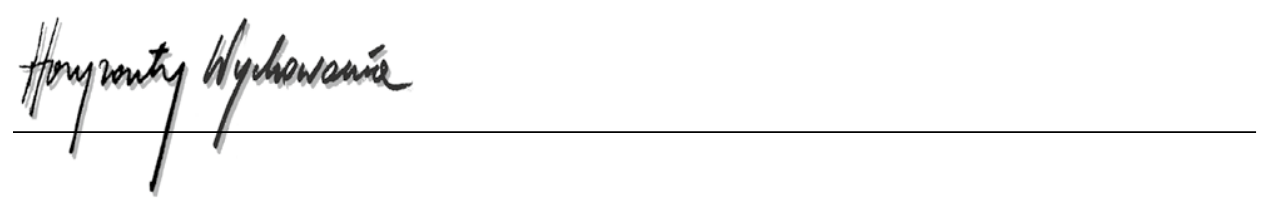

at work. I try to reconcile motherhood with work. I am not afraid to ask for help in looking after the child.

I do not pretend I am a perfect mother, because such mothers don't exist. I can admit that I am tired. I can admit that I can't cope. I and my husband both work, we bring up two children and support each other. We have no division into man's and woman's tasks. We complement each other. We rely on each other. My husband participates very actively in bringing up our children and helping at home.

More and more often, mothers admit openly they do not want to be "full-time mothers." The monotony of daily life is often the reason why women-mothers get back to work. Women feel tired with everydayness and want to renew contacts with other people. They lack energy and "time for themselves" (Sikorska, 2012, p. 112). This is exemplified by the following statements:

I am so tired staying at home with my child that I would like to go back to work. This is monotony. I want to return to work to get some rest from this dailiness. To get away. I don't want to be only a mother...

so tired with all this. I have no strength left in me for anything. I think I am a bad mother. Spending time with my child does not give me pleasure. Every day is the same. Routine. Changing the baby, putting the clothes on and off, feeding, putting the baby to sleep. Over and over again. Incessantly. I can't find a minute for myself. I am totally frustrated. I have had it.

Though having a child requires (at least temporary) renunciation of some activities and it causes fatigue and frustration, the surveyed women all agree that the child compensates for all these difficulties by giving love and warmth which cannot be experienced by someone who has no children.

Sometimes I am so exhausted that I just fall flat on my face. But I have never wanted to turn
back time. Despite all the renunciations there are more pros than cons. Before I become
a mother I had been totally unaware that a child could give so much love, warmth and
support. It is difficult to explain.

The child is most important to me. It is awaited. Longed for. It is not a dreary duty for me. I love spending time with my child. Seeing him grow and develop. The progress he makes each day.

Spending time with the child is seen as a pleasure, not a duty. A child is a value as such. Motherhood comes to be defined first of all by emotional determinants: a mother discovers love for the child in herself and enjoys being with the child. It often happens that the meaning of life is redefined, since the child becomes the focus of attention.

The source of this fatigue is identified also in the (lack of) support from the partner. The manner in which the respondents spoke about such situations allows to categorize their statements. One may identify situations when women do not get the support and 
have to face all problems on their own as well as situations when they get the support. The first category is exemplified by the following statements:

I wonder if there is any point of making comments... because nothing changes anyway. I honestly doubt anything would change. People talk a lot about the partnership model. But real life is different. I am the one who looks after our child most of the time. My husband focuses on work. He thinks it is his task to provide for the family. I am left alone with all of this. I wake up in the morning and I already feel tired when I just think about the next 12 hours of looking after my little child. I hope this time will quickly pass and I will be able to go back to work. To life.

He leaves me alone with all this. He helps with practically nothing. This makes me even more tired. When he comes home, he asks me what I have been doing all day, sitting at home... It makes no sense to actually try, what is the point?

Despite the generally accepted partnership model, the majority of childcare duties are performed by the mother. The above statements contain a clear message concerning the lack of support, but they also point to the sense of loneliness felt by the surveyed women.

The contemporary times put an emphasis on the role of the father who takes a more active part in bringing up and looking after the child. The respondents include womenmothers who function in a partnership model and enjoy the support of their partners.

\section{Instead of a conclusion}

Changes in civilisation, economy and culture have led to the emergence of new ways to construct scenarios related to the performance of social roles. The contemporary daily life initiated flexibility (unseen before) in the interpretation of normative regulations of behavioural models. Furthermore, values are understood equivocally (in a relativist manner - addition by M.L.). Contemporary people have more confidence in their opportunities and make personal interpretations and modifications of social expectations (Wrzesień, 2016, p. 39).

It is possible to draw a conclusion that motherhood is in transition from the traditional and the modern model of the ideal mother. The mother's role is under the influence of social expectations and the culture of individualism which made it possible for people to have a fuller participation in the social life and possibilities of choice. The price for this freedom is the burden of responsibility for the consequences of decisions and the sense of guilt in a situation when the choice turns out to be subjectively wrong. First of all, mothers feel tired with the importance attached to their role and with the fact that many people may held them accountable in relation to the performance of this role.

The externally imposed way of performing the parent role can be perceived as oppressive and inducing the sense of injustice, frustration and disorientation. Some women-mothers give in to this real or imagined coercion, while others consistently follow their own vision of motherhood. Either choice results in specific consequences (Gajtkowska, 2016, p. 79). 


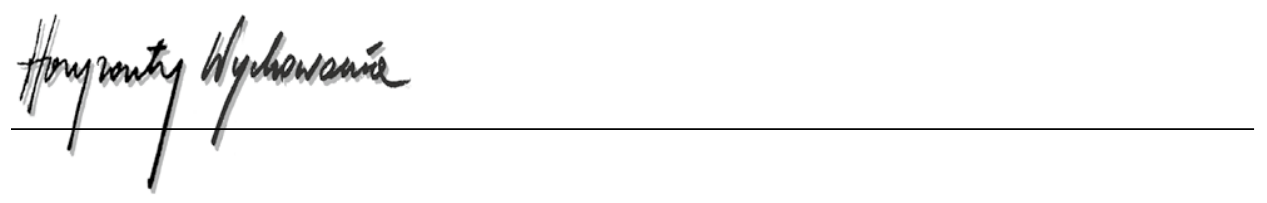

According to Winnicott (2011), a British psychoanalyst and paediatrician, a good mother cares for and allows the child to discover the world and his or her individuality. The mother's relationship with her child is based on moderation, attention, acceptance as well as spontaneous and adequate reactions. Winnicott defines the first condition of successful motherhood is the ability to adjust to the child's needs, while the first virtue of a father is the allow the woman to be a "good mother" (Bieńko, 2015, p. 94).

\section{Implications:}

- Modern mothers find themselves faced with the need for a constant choice, which concern both the meaning they give to their motherhood and social expectations that are placed before them.

- The externally prescribed way of carrying out the parental role can be understood as oppressive, which is the source of a sense of injustice, frustration, loss, fatigue. Mothers feel, above all, tired of the seriousness of the role that is theirs, and from which many people can "account for" them.

- It can be concluded that the idealisation of motherhood works to the detriment of modern women. They are often fraught with expectations that they are unable to meet.

- Mothers try to break the public expectations placed on them and reject the image created by most media reports of a mother who "devotes herself" completely and unconditionally to her child.

- In regarding a sense of balance, a support network is essential, which should be provided by the immediate family, father and other "significant persons."

- It seems important to point to a model of motherhood that allows uncertainty and fatigue. Motherhood that is not perfect but "good enough."

\section{BIBLIOGRAPHY}

Bieńko M. (2015), Perfekcyjna matka oraz bachor w poradnikach i bezradnikach współczesnej popkultury. In I. Taranowicz \& S. Grotowska (eds.), Rodzina wobec wyzwań współczesności. Wybrane problemy (pp. 91-106). Wrocław: Oficyna Wydawnicza Arboretum.

Budrowska, B. (2000). Macierzyństwo jako punkt zwrotny w życiu kobiety. Wrocław: Fundacja na Rzecz Nauki Polskiej.

Creswell, J.W. (2013). Projektowanie badań naukowych. Metody jakościowe, ilościowe i mieszane (J. Gilewicz, Trans.). Kraków: Wydawnictwo UJ.

Gajtkowska, M. (2016). Rola matki jako obszar dylematów współczesnych kobiet. Badania własne. Przegląd Pedagogiczny, 1, 77-90.

Gawlina, Z. (2003). Macierzyństwo jako wartość w kontekście przemian społecznych. Blaski i cienie życia rodzinnego. Roczniki Socjologii Rodziny, 15, 33-45.

Jakob, G. (2001), Wywiad narracyjny w badaniach biograficznych. In D. Urbaniak-Zając \& J. Piekarski (eds.). Jakościowe orientacje w badaniach pedagogicznych (pp. 111-126). Łódź: Wydawnictwo Uniwersytetu Łódzkiego. 
Konarzewski, K. (2000). Jak uprawiać badania oświatowe. Metodologia praktyczna. Warszawa: Wydawnictwa Szkolne i Pedagogiczne.

Lalak, D. (2010). Podejście biograficzne (biograficzność) w naukach o wychowaniu. Trzy perspektywy dyskursu. In S. Palka (ed.), Podstawy metodologii badań w pedagogice (pp. 257-280). Gdańsk: Wydawnictwo GWP.

Mitręga, A. (2014). Matczyne debiuty. Obrazy doświadczania pierwszych tygodni macierzyństwa. Kultura - Społeczeństwo - Edukacja, 1(5), 55-74.

Nowak-Dziemianowicz, M. (2002). Doświadczenia rodzinne w narracjach. Interpretacje sensów i znaczeń. Wrocław: Wydawnictwo Uniwersytetu Wrocławskiego.

Ostrouch-Kamińska, J. (2011). Rodzina partnerska jako relacja współzależnych podmiotów. Studium socjopedagogiczne narracji rodziców przeciążonych rolami. Kraków: Wydawnictwo Impuls.

Palus, K. (2010). Wybrane psychologiczne uwarunkowania braku partnera życiowego w okresie wczesnej dorosłości. Poznań: Wydawnictwo Naukowe Wydziału Nauk Społecznych Uniwersytetu im. Adama Mickiewicza.

Rubacha, K. (2008). Metodologia badań nad edukacją. Warszawa: Wydawnictwa Akademickie i Profesjonalne.

Sikorska, M. (red.). (2012). Ciemna strona macierzyństwa. O niepokojach współczesnych matek. Raport. Warszawa: AXA. https://www.uniqa.pl/fileadmin/produkty/centrum_klienta/aktualnosci/ raport_ciemna_strona_macierzynstwa_maj_2012.pdf

Skoczylas-Namielska, E. (2020). Codzienność - niecodzienność w wypowiedziach osób starszych. Pedagogika Społeczna, 2(76), 165-184.

Smolińska-Theiss, B. \& Theiss, W. (2010). Badania jakościowe - przewodnik po labiryncie. In S. Palka (ed.). Podstawy metodologii badań w pedagogice (pp. 79-102). Gdańsk, Wydawnictwo GWP.

Sulik, M. (2017). W poszukiwaniu (od)cieni macierzyńskich doświadczeń - peregrynacje andragogiczno-biograficzne. Edukacja Dorosłych, 1, 79-89.

Trempała, J. (2000). Modele rozwoju psychicznego. Czas i zmiana. Bydgoszcz: Wydawnictwo Uniwersytetu Kazimierza Wielkiego.

Winnicott, D.W. (2011). Dom jest punktem wyjścia. Eseje psychoanalityczne. (A. Czownicka, Trans.). Gdańsk: Wydawnictwo Imago.

Włodarczyk, E. (2017). Misja „mama”. Wyzwania i trudności. In E. Włodarczyk (ed.), W trosce o macierzyństwo (pp. 53-68). Poznań: Wydawnictwo Naukowe UAM.

Wrzesień, W. (2016). Rodzinne (post)role w ponowoczesności. In I. Przybył \& A. Żurek, Role rodzinne. Między przystosowaniem a kreacją (s. 39-48). Poznań: Wydawnictwo Naukowe Wydziału Nauk Społecznych UAM w Poznaniu.

Wysocka, E. (2010). Życie codzienne w percepcji i doświadczaniu młodzieży. In E. Syrek (ed.), Czas społeczny akademickiego uczestnictwa w rozwoju i doskonaleniu civil society. Księga jubileuszowa dedykowana profesorowi Andrzejowi Radziewiczowi-Winnickiemu w 65. rocznice urodzin (s. 396-409). Katowice: Wydawnictwo Uniwersytetu Śląskiego.

\section{Copyright and License}

This article is published under the terms of the Creative Commons Attribution - NoDerivs (CC BY- ND 4.0) License http://creativecommons.org/licenses/by-nd/4.0/ 